3

\title{
Sensus Daerah: Mengembangkan Sistem Administrasi Kependudukan dalam Rangka Otonomi Daerah ${ }^{1}$
}

\author{
Dwi Sadono
}

\begin{abstract}
Ringkasan
Perencanaan pembangunan yang baik memerlukan tersedianya data dasar (baseline data) sumberdaya yang dimilikinya (manusia, alam, ekonomi, dan sebagainya) yang baik dari negara/daerah yang bersangkutan. Salah satu data dasar yang diperlukan adalah data dasar mengenai administrasi kependudukan. Pentingnya administrasi kependudukan yang baik semakin dirasakan daerah dalam era otonomi daerah. Tanpa tersedianya data dasar yang baik maka dapat membuat banyak kebijakan yang kurang tepat sasaran. Dengan tersedianya "bank data" melalui Sensus Daerah dengan basis data setiap warga menurut daftar nama (by name) dan menurut daftar alamat (by address) secara berjenjang mulai dari tingkat Rukun Tetangga (RT) hingga tingkat kabupaten dan selalu diperbaharui secara simultan, maka akan dapat dijadikan sebagai acuan yang memadai dalam menetapkan kebijakan maupun program pembangunan daerah yang lebih efektif.
\end{abstract}

Kata kunci: administrasi kependudukan, otonomi daerah, sensus daerah, baseline data kependudukan, efektivitas program.

\section{Pendahuluan}

Penyelenggaraan administrasi kependudukan yang telah dilakukan pemerintah selama ini antara lain didasarkan pada Keppres No. 52 Tahun 1977 tentang Pendaftaran Penduduk dengan pedoman pelaksanaan-nya adalah Permendagri No. 8 Tahun 1977. Acuan lainnya adalah UU No. 10 Tahun 1992 tentang Perkembangan Kependudukan dan Pembangunan Keluarga Sejahtera. Dalam pasal 8 ayat 3 dari UU tersebut ditegaskan pentingnya penyelenggaraan pencatatan kejadian vital (kelahiran, kematian, pindah, dsb.) yang dialami penduduk sebagai sarana memantau perkembangan, keselarasan dan keseimbangan penduduk yang diukur dari kualitas diri dan kualitas lingkungan hidup penduduk. Dasar lainnya adalah PP No. 27 Tahun 1994 tentang

1 Perbaikan dari makalah yang disampaikan ke Bappeda Kabupaten Bogor dalam rangka Sensus Daerah Kabupaten Bogor 2006.

2 Staf Pengajar Departemen Komunikasi dan Pengembangan Masyarakat IPB, mengasuh mata kuliah Ilmu Penyuluhan dan mata kuliah Pendidikan Orang Dewasa, alamat email: dwsadono@yahoo.com. 
Pengelolaan Perkembangan Kependudukan dimana dinyatakan bahwa penyelengaraan sistem informasi perkembangan kependudukan diperlukan dalam mendukung perumusan kebijakan pembangunan dan lingkungan hidup.

Meskipun telah dikeluarkan berbagai peraturan yang mengatur perlunya tertib administrasi kependudukan, Haryanto dan Sugeng (2001) menemukan bahwa upaya-upaya mengintensifkan pelaksanaan pendaftaran penduduk sebagai sarana menertibkan administrasi penduduk guna memantau perkembangan kependudukan masih jauh dari harapan. Hal ini menyebabkan data tersebut belum dapat dimanfaatkan secara baik sebagai dasar perencanaan pembangunan.

Ada beberapa alasan mengapa data kependudukan di Indonesia belum dapat dimanfaatkan secara baik sebagai dasar perencanaan kebijakan pembangunan. Pertama, selama ini kebijakan pembangunan sektoral dan bidang kependudukan di tingkat nasional, regional maupun lokal, perumusannya masih didasarkan atas data hasil Sensus Penduduk (SP) yang diselenggarakan oleh Badan Pusat Statistik (BPS) setiap sepuluh tahun. Data kependudukan lainnya yang menjadi dasar perencanaan atau pembangunan adalah data proyeksi penduduk dan data hasil survei kependudukan tingkat nasional seperti Survei Sosial Ekonomi Nasional (Susenas), Survei Ketenagakerjaan Nasional (Sakernas), Survei Demografi dan Kesehatan Indonesia (SDKI).

Data tentang jumlah penduduk setelah tahun pelaksanaan sensus yang diperlukan untuk dasar perencanaan pembangunan umumnya dibuat melalui prakiraan atau proyeksi penduduk. Proyeksi dibuat dengan menggunakan asumsi berdasarkan kecenderungan dan arah perkembangan kependudukan dari hasil analisis keadaan sebelumnya. Oleh karena itu, seringkali ditemukan berbagai kebijakan pembangunan yang dirumuskan tidak sesuai dengan kondisi kependudukan yang ada di lapangan pada saat dilakukan intervensi program. Hal ini karena asumsi yang disusun tidak sesuai dengan perkembangan kependudukan yang terjadi.

Kedua, pelaksanaan administrasi dan informasi kependudukan masih sangat bervariasi antar daerah, terpisah-pisah oleh beberapa instansi dan belum ada koordinasi atau usaha mengintegrasikan ke dalam suatu sistem. Pencatatan yang dilakukan umumnya hanya berorientasi untuk kebutuhan internal sektor. Masing-masing instansi meskipun telah mengesahkan kejadian vital, tetapi secara umum belum semuanya menghimpun catatan atau ada pihak yang mengkoordinir untuk menghimpun dan menyatukan data yang dicatat ke dalam sistem yang terintegrasi.

Ketiga, cakupan datanya masih terbatas. Hal ini didukung dari laporan tahunan yang dikeluarkan PBB tahun 1998 dimana administrasi kependudukan di Indonesia termasuk kategori III dengan tingkat cakupan sekitar $50-60 \%$. Cakupan pendaftaran dan pencatatan kejadian vital yang sangat rendah ini menyebabkan data/informasi kependudukan di Indonesia belum bisa dimanfaatkan sebagaimana mestinya. 
Keempat, dalam rangka penetapan sasaran program pembangunan di daerah untuk mengatasi permasalahan yang dialami penduduk secara langsung seringkali tidak dapat berjalan efektif, yang disebabkan karena tidak tersedianya data mikro penduduk. Selama ini, basis data yang terhimpun belum bertitik tolak dari setiap warga menurut daftar nama (by name) maupun menurut daftar alamat (by address) serta aspek lainnya yang telah terbangun dalam sebuah sistem informasi dan administrasi kependudukan secara berjenjang, mulai dari Rukun Tetangga (RT), Rukun Warga (RW) dan seterusnya ke atas sampai tingkat kabupaten bahkan nasional. Data yang selama ini tersedia, tiada lain adalah rekapitulasi "angka per angka" di setiap daerah. Keadaan tersebut seringkali juga sangat menghambat upaya-upaya penanganan masalah kependudukan lainnya yang harus diatasi.

Ketiadaan data mikro yang memadai menyebabkan program-program menjadi bias kebutuhan dan bias pemanfaat (subyek/sasaran) sehingga program menjadi tidak efektif, yaitu tidak mengatasi masalah yang sebenarnya dan tidak mencapai sasaran yang seharusnya dikenai program (Agusta, 2000, Tetiani, 2002).

Ketidak-efektifan program-program tersebut ditunjang dengan kebiasaan selama ini dalam penanganan program. Program yang dilaksanakan oleh pemerintah dilaksanakan dengan pendekatan proyek, yang biasanya mempunyai batas waktu pelaksanaan yang relatif sempit (terikat tahun anggaran pemerintah, 1-3 tahun). Pelaksanaannya seringkali dilakukan dengan tergesa-gesa karena dananya juga sering terlambat realisasinya. Program dilaksanakn dengan pendekatan management by objective (manajemen keterlaksanaan proyek) (Utomo, 1998). Keberhasilan proyek dinilai dengan mengevaluasi tingkat realisasi target. Cara yang paling gampang dalam menilai keberhasilan program adalah total dana yang telah dialokasikan dalam DIP tahun anggaran yang bersangkutan.

Apabila kelemahan-kelemahan dari sistem penyelenggaraan administrasi dan informasi kependudukan dapat diatasi, maka banyak manfaat yang akan dapat diperoleh. Termasuk di dalamnya dalam rangka mendukung pelaksanaan otonomi daerah yang telah menjadi tekad pemerintah untuk dilaksanakan dengan berhasil mulai tahun 2001. Dengan adanya tertib administrasi kependudukan yang dapat diwujudkan secara menyeluruh sampai ke tingkat desa, maka upaya untuk menghimpun data dan informasi perkembangan kependudukan untuk semua tingkatan secara berjenjang mulai dari desa sampai ke tingkat pusat akan lebih terjamin pelaksanaannya.

\section{ADMINISTRASI KEPENDUDUKAN DAN OTONOMI DAERAH}

Perhatian yang meningkat terhadap kebijaksanaan desentralisasi pembangunan di negara-negara sedang berkembang muncul karena beberapa alasan (Ingham dan Kalam, 1992). Pertama, karena adanya ketidakpuasan atas hasil kegiatan perencanaan, pelaksanaan, dan pengendalian pembangunan pada periode 1960-an yang sangat sentralistis. Kedua, desentralisasi merupakan 
strategi baru dalam pelaksanaan program-program pembangunan yang mendukung kebijakan pertumbuhan dan keadilan pada tahun 1970-an. Ketiga, karena masyarakat semakin kompleks dan kegiatan pemerintahan semakin besar dan meluas. Akibatnya muncul kesulitan untuk merencanakan dan melaksanakan program-program pembangunan secara efektif dan efisien dari level pusat.

Menurut kamus umum Bahasa Indonesia, kata otonom berarti memerintah dan mengurus sendiri, sedangkan otonomi berarti pemerintahan sendiri $($ auto $=$ sendiri, nomes $=$ pemerintahan). Manan dalam Mustari (1999) mendefinisikan otonomi sebagai :"kebebasan dan kemandirian satuan pemerintahan yang lebih rendah untuk mengatur dan mengurus sebagian urusan pemerintahan. Kebebasan dan kemandirian merupakan hakekat isi otonomi".

Bienen, et al. (1990) mendefinisikan konsep desentralisasi dari perspektif administratif. Desentralisasi merupakan pengalihan tanggung jawab dalam perencanaann, manajemen, dan peningkatan alokasi sumberdaya dari pemerintah pusat ke pemerintah regional, semi otonom, unit sub ordinat, dan organisasi non pemerintah. Sejalan dengan itu, desentralisasi merupakan pengalihan kekuasaan-kekuasaan dan fungsi-fungsi serta kegiatan-kegiatan dari pemerintah pusat ke pemerintah regional, kabupaten, dan unit administratif atau geografis lainnya (1994).

Menurut Zuhro (1999), prinsip yang terkandung dalam otonomi adalah masalah kekuasaan untuk mengelola sendiri sumber ekonomi dan kebijakan politik. Secara filosofis-ideologis, otonomi daerah dapat dipandang sebagai suatu mekanisme yang memungkinkan tumbuhnya partisipasi yang luas bagi masyarakat dan mendorong daerah agar mampu membuat keputusan sendiri tanpa harus tergantung pada kebijakan pemerintah pusat. Pada tingkatan yang lebih pragmatis, otonomi merupakan suatu strategi untuk mengatasi hambatan institusional fisik maupun hambatan-hambatan administrasi. Dengan kata lain, otonomi merupakan suatu upaya untuk mendorong proses demokratisasi yang memberikan kebebasan masyarakat lokal untuk mengatasi masalahnya sendiri yang bersifat lokal.

Secara keseluruhan, menurut Mayo (1994) desentralisasi mempunyai tiga tujuan umum. Pertama, untuk memfasilitasi partisipasi lokal dalam perencanaan program pembangunan yang lebih relevan dengan kebutuhan dan kondisi lokal. Kedua, untuk meningkatkan efisiensi, efektifitas, dan fleksibilitas dalam implementasi program dan koordinasi antara lembagalembaga terkait pada tingkat lokal. Ketiga, untuk memperkuat kesatuan nasional dengan pemberian otonomi dan tanggung jawab pada otoritas lokal.

Otonomi daerah dalam Bab I mengenai Ketentuan Umum UU No. 22/1999 dijelaskan sebagai kewenangan daerah otonom dalam mengatur dan mengurus kepentingan masyarakat setempat menurut prakarsa sendiri berdasarkan aspirasi masyarakat dalam ikatan Negara Kesatuan Republik Indonesia (NKRI). Kemudian dalam bagian Penjelasan dikatakan bahwa 
penyelenggaraan otonomi daerah dilaksanakan dengan memberikan kewenangan yang luas, nyata dan bertanggung jawab kepada daerah secara proporsional yang diwujudkan dengan pengaturan, pembagian, dan pemanfaatan sumberdaya nasional yang berkeadilan, serta perimbangan keuangan pemerintah nasional dan daerah. Disamping itu, penyelenggaraan otonomi daerah juga dilaksanakan dengan prinsip-prinsip demokrasi, peranserta masyarakat, pemerataan dan keadilan, serta memperhatikan potensi dan keanekaragaman daerah.

Dari hal tersebut di atas, maka kebijakan otonomi daerah sebagaimana gagasannya yang tertuang pada UU No. 22 Tahun 1999 dan revisinya pada UU No. 32 Tahun 2004 tentang Pemerintah Daerah menjadi salah satu landasan perubahan sistem tata pengaturan atau tata pemerintahan (governance system) yang penting dalam sejarah pembangunan politik dan pengelolaan administrasi pemerintahan secara nasional di Indonesia. UU tersebut di atas memiliki "ruh" atau ideologi tentang kesetaraan para pihak pemangku kekuasaan, kemandirian, kesejahteraan sosial, demokratisme, partisipasi, keberdayaan masyarakat, dan tata kelola pemerintahan yang baik.

Dalam konsepnya, otonomi daerah (sesuai UU No. 22/1999 dan revisinya pada UU No. 32/2004) secara eksplisit maupun implisit hendak mengedepankan cita-cita penegakan prinsip-prinsip demokratisme (kesetaraan, kesejajaran, etika egalitarianisme), keunggulan lokal, komitmen pada rule of the game yang telah disepakati, apresiasi terhadap keberagaman, prinsip bottom up, desentralisme administratif yang elegan dan berwibawa di tingkat lokal serta berkemampuan mengatasi persoalan riil di lapangan, penghargaan pada prakarsa serta hak-hak politik masyarakat lokal, kemandirian dan kedaulatan sistem sosial ekonomi lokal serta pembebasan dari segala bentuk ketergantungan sosial politik pada semua pihak (Dharmawan, 2006).

Sehubungan dengan hal di atas, lalu dimana dan bagaimana peran yang dapat dilakukan pemerintah kabupaten/kota dalam kaitannya dengan administrasi kependudukan? Penduduk suatu negara pada kenyataannya merupakan individu-individu yang menjadi bagian dari suatu keluarga dan komunitas yang menempati suatu lokasi wilayah untuk bermukim dan mendapat penghidupan. Lokasi tempat tinggal penduduk itu merupakan bagian dari administrasi tertentu dari pemerintah. Pemerintah kabupaten/kota, dimana titik berat otonomi daerah diletakkan, merupakan administrasi yang paling dekat dengan individu penduduk, keluarga, dan komunitasnya. Oleh karena itu kewenangan untuk melaksanakan regristrasi penduduk harus diberikan kepada pemerintah kota/kabupaten.

Dalam era otonomi daerah, apakah peraturan mengenai kependudukan menjadi kewenangan pemerintah kabupaten/kota? Di bagian mana dalam pengaturan tertib administrasi kependudukan itu pemerintah pusat dan daerah dapat berbagi kewenangan?

Tugas penyelenggaraan administrasi dan informasi kependudukan dalam rangka otonomi daerah telah diatur kembali melalui UU No. 22 Tahun 1999 tentang Pemerintahan Daerah serta PP No. 25 Tahun 2000 tentang 
Kewenangan Pemerintah dan Kewenangan Propinsi sebagai Daerah Otonom. Dalam PP tersebut ditetapkan bahwa Pemerintah (Pusat) di bidang Politik Dalam Negeri dan Administrasi Publik memiliki kewenangan menetapkan Pedoman Administrasi Kependudukan dan untuk Bidang Lainnya memiliki kewenangan menetapkan kebijakan Sistem Informasi Nasional termasuk bidang Kependudukan. Dalam rangka implementasi atau pelaksanaan administrasi dan informasi kependudukan sesuai dengan kewenangan dalam penyelenggaraan otonomi daerah dilaksanakan oleh Pemerintah Kota/Kabupaten (Haryanto dan Sugeng, 2001). Apa yang kemudian dapat dilakukan oleh pemerintah daerah kabupaten/kota untuk mengatur administrasi kependudukan di daerahnya?

Berkaitan dengan sitem administrasi kependudukan dalam rangka otonomi daerah, maka sistem registrasi penduduk dapat ditentukan oleh pemerintah kabupaten/kota sendiri sesuai dengan kebutuhannya dan ciri sumberdaya manusia dan sumberdaya alam yang dimiliki (Haryanto dan Tjondronegoro, 2001; Wahyuni, 2003). Dalam kaitan dengan masalah migrasi penduduk misalnya, jika daerah tersebut mempunyai potensi menarik migran dari luar, maka dapat dibuat aturan yang lebih ketat menyangkut penduduk pendatang tersebut. Apakah daerah tersebut mengeluarkan surat penduduk sementara bagi pendatang yang mau tinggal di daerahnya dan kemudian memberikan kartu penduduk permanen jika pendatang tersebut telah memenuhi syarat sebagai penduduk tetap. Demikian juga halnya dengan daerah yang banyak mengirim migran keluar. Mereka perlu membekali surat jalan dan pada waktu tertentu mengadakan pengecekan atas keberadan penduduknya tersebut. Jika ada warganya yang akan pindah ke tempat lain secara permanen, maka daerah pengirim memberikan surat pindah.

Dengan sistem registrasi yang tertib, pemerintah daerah kabupaten/kota akan dapat mengontrol penduduknya dimanapun berada dan memberikan perlindungan kepada mereka. Kontrol penduduk yang pindah atau masuk dilakukan melalui keluarga dan komunitasnya.

Untuk menjamin tertib pelaksanaan kebijakan gerak penduduk ini, Wahyuni (2003) melihat perlu adanya kesepakatan antar pemerintah daerah kabupaten/kota agar peraturan yang berlaku di suatu daerah dapat dipahami oleh daerah-daerah lain, sehingga jika ada penduduknya yang bermasalah di daerah tersebut maka pemerintah daerah asal dapat membantu. Disamping itu, antar daerah perlu mempunyai sistem pelaporan yang sama yang dikontrol oleh propinsi agar dari pelaporan tersebut, propinsi dapat menyusun rekapitulasi perubahan penduduk yang terjadi pada periode tertentu.

\section{SENSUS DAERAH: SUATU KEPERLUAN MENDASAR?}

Seperti telah disebutkan di atas, bahwa dalam rangka implementasi atau pelaksanaan administrasi dan informasi kependudukan sesuai dengan kewenangan dalam penyelenggaraan otonomi daerah, maka pelaksanaannya 
dilakukan oleh pemerintah kabupaten/kota. Agar dapat memenuhi keperluan pendataan untuk daerahnya disamping keperluan pusat, maka sistem registrasi penduduk perlu ditentukan oleh pemerintah kabupaten/kota sesuai dengan kebutuhannya dan ciri sumberdaya manusia dan sumberdaya alamnya. Oleh karena itu Sensus Daerah atau disingkat SUSDA menjadi suatu kebutuhan mendasar untuk dapat memenuhi maksud di atas.

Sensus Penduduk didefinisikan sebagai keseluruhan proses pengumpulan (collecting), menghimpun dan menyusun (compiling) dan menerbitkan data-data demografi, sosial dan ekonomi yang menyangkut semua orang pada waktu tertentu di suatu negara atau suatu wilayah tertentu. Dari definisi di atas, terdapat tiga karakteristik dari sensus penduduk, yaitu: (1) Semua orang, artinya semua orang atau penduduk (yang hidup) dalam wilayah yang dicacah haruslah tercakup, (2) Waktu tertentu, artinya sensus haruslah dilakukan pada saat tertentu yang telah ditetapkan dan harus dilaksanakan secara serentak, dan (3) Suatu wilayah tertentu, artinya ruang lingkup sensus harus meliputi batas wilayah tertentu.

Sensus Daerah (SUSDA) yang dilakukan oleh pemerintah Kabupaten/ Kota, adalah suatu kegiatan sensus penduduk yang dimaksudkan untuk menyediakan basis data yang terbangun dan terintegrasi ke dalam sebuah sistem informasi SUSDA, yang komprehensif dan selalu terbarukan datanya karena ada sistem updating yang berlanjut. Dengan demikian akan tersedia "bank data" atau data yang komprehensif dan up to date bagi penyelenggaraan Pemerintah Kabupaten/Kota serta pelayanan data dan informasi kepada masyarakat pada masa yang akan datang.

SUSDA yang dilakukan oleh Pemerintah Kabupaten/Kota ini adalah sebagai suatu terobosan atau semacam "revolusi data" atau perubahan mendasar atas basis data demografi, sosial dan ekonomi dari seluruh penduduk suatu Kabupaten/Kota. Basis data yang tersedia selama ini (Sensus Penduduk, SUPAS, SUSENAS, dan sebagainya) belum bertitik tolak dari setiap warga menurut daftar nama (by name) maupun menurut daftar alamat (by address) serta aspek lainnya yang diperlukan, tetapi masih berupa rekapitulasi "angka per angka". Oleh karena itu, bagi Pemerintah Kabupaten/Kota, hal ini seringkali dirasakan tidak memadai untuk dijadikan sebagai acuan untuk menetapkan kebijakan maupun program pembangunan daerah.

Dengan tersedianya "bank data" melalui SUSDA dengan basis data setiap warga menurut daftar nama (by name) dan menurut daftar alamat (by address) secara berjenjang mulai dari tingkat Rukun Tetangga (RT) hingga tingkat kabupaten dan selalu diperbaharui secara simultan, maka akan dapat dijadikan sebagai acuan yang memadai dalam menetapkan kebijakan maupun program pembangunan daerah.

Pembaharuan data secara simultan ini akan dapat dilakukan jika semua pihak, baik penduduk maupun aparat pemerintah di berbagai level sadar dan bersedia melakukan pencatatan kependudukan secara tertib. Namun demikian, untuk pemutakhiran data secara menyeluruh maka masih diperlukan pendataan ulang melalui sensus secara periodik (5 atau 10 tahun). Masalahnya 
adalah, apakah sensus-sensus berikutnya dapat dilaksanakan secara terintegrasi dengan pelaksanaan Sensus Penduduk secara nasional? Hal ini untuk menghindari pendataaan yang berulang-ulang di masyarakat dan kemungkinan melakukan penghematan biaya dalam pelaksanaan sensus.

\section{MANFAAT TERTIB ADMINISTRASI KEPENDUDUKAN}

Administrasi kependudukan yang tertib akan dapat memberi manfaat kepada berbagai pihak yang memerlukan data kependudukan tersebut, baik individu, pemerintah, maupun pihak yang berkepentingan. Beberapa manfaat tertib administrasi kependudukan (Haryanto dan Sugeng, 2001) adalah:

1. Bagi individu, kesediaan untuk mendaftarkan dan mencatatkan kejadian vital yang dialami yang ditandai dengan pemilikan dokumen kependudukan seperti akte, sertifikat, surat keterangan, dan lainnya, akan memperoleh keabsahan dan kepastian status hukum dirinya sehubungan dengan kejadian vital yang dialaminya. Hal ini akan memudahkan yang bersangkutan mendapatkan haknya memperoleh pelayanan publik.

2. Bagi pemerintah, pendaftaran dan pencatatan kejadian vital selain untuk pengesyahan bagi kejadian yang dialami penduduk, juga untuk keperluan statistik kependudukan. Dengan menghimpun, mengolah serta menganalisis data hasil pendaftaran dan pencatatan yang tertib tersebut akan diperoleh suatu informasi kependudukan yang lebih akurat dibandingkan dengan sumber data yang lain.

3. Bagi pihak-pihak lain, pembuatan statistik kependudukan berdasarkan pencatatn kejadian vital akan memberikan informasi yang sangat penting untuk berbagai kegiatan, seperti: pelayanan kesejahteraan sosial, bisnis, asuransi, perbankan, dan lain-lain. Dengan menghimpun data kematian menurut umur dan jenis kelamin maka akan dapat dibuat tabel kematian (Life Table). Tabel kematian ini sangat berguna untuk membuat berbagai prediksi kependudukan di masa mendatang.

4. Bagi pihak-pihak yang berminat memanfaatkan keberadaan data dan dokumen kependudukan untuk kepentingan publik, maka penyelenggaraan administrasi kependudukan yang tertib akan memudahkan mendapat alat bantu untuk menguji kebenaran dan keabsahan data pribadi seseorang.

\section{PENGEMBANGAN SISTEM ADMINISTRASI KEPENDUDUKAN}

Banyak faktor yang menyebabkan kualitas penyelenggaraan administrasi kependudukan di Indonesia selama ini belum mampu berjalan seperti yang diharapkan. Hal ini, seperti yang telah disinggung di bagian awal tulisan, seringkali menyebabkan ketidaktepatan dalam pengambilan keputusan 
mengenai kebijakan dan program pembangunan yang akan diambil serta penetapan sasarannya.

Oleh karena itu beberapa hal yang dapat dan perlu dilakukan untuk mengembangkan sistem tertib administrasi kependudukan adalah:

1. Penyelenggaraan administrasi kependudukan termasuk pendaftaran dan pencatatan kejadian/peristiwa vital yang selama ini ditangani oleh berbagai instansi atau sektor, dan sekarang mungkin masih akan dilakukan, maka perlu ada pihak atau organisasi yang bertanggung jawab yang mengkoordinir untuk menghimpun dan menyatukan data yang dicatat oleh berbagai instansi ke dalam suatu sistem yang terintegrasi. Kantor BPS Kabupaten dapat dijadikan sebagai penanggung jawab yang mengkoordinir untuk menghimpun dan menyatukan data yang dicatat oleh berbagai instansi.

2. Perlunya memperluas cakupan pencatatan, ketepatan waktu pelaporan dan adanya pengolahan mutasi penduduk. Kelemahan proses pendaftaran dan pencatatan yang dilakukan instansi fungsional yang selama ini dilakukan, khususnya dalam hal kelahiran, kematian, dan perpindahan umumnya belum mampu menghimpun data kependudukan yang tepat waktu, menghasilkan data yang akurat, dengan cakupan yang menyeluruh. Dengan pencatatan data yang tepat waktu, akurat dan cakupan yang menyeluruh, maka akan dapat diolah dan dianalisis yang baik sehingga menghasilkan statistik kependudukan yang dapat dipercaya.

3. Perlunya komitmen dan kesadaran bersama antara aparat dan masyarakat. Kesadaran akan kebutuhan data kependudukan yang tepat dan akurat sampai tingkat desa ini sebetulnya sudah mulai dirasakan, terlebih-lebih dengan adanya reformasi dan perubahan paradigma pemerintahan yang mengarah kepada otonomi yang luas di kabupaten/kota. Selain itu, untuk penanganan kesejahteraan penduduk diperlukan realisasi pembangunan yang lebih berorientasi kepada kepentingan rakyat. Kebutuhan data penduduk seperti untuk pelaksanaan pemilu, dana JPS, bantuan penduduk miskin, dan sebagainya, memerlukan kualitas dan validitas data yang dapat dipertanggung jawabkan. Oleh karena itu, komitmen dan dukungan semua pihak untuk penyelenggaraan administrasi kependudukan yang tertib dan menyeluruh masih perlu ditingkatkan.

4. Perlunya landasan hukum yang mengikat untuk pendaftaran dan pencatatan kejadian vital. Peraturan perundang-undangan yang mengatur perlunya registrasi penduduk, mutasi penduduk, dan sebagainya, telah dikeluarkan mulai dari UU, PP, Permendagri, dan sebagainya. Meskipun demikian, peraturan-peraturan tersebut belum mengatur tentang kewajiban yang mengikat disertai sanksi hukum kepada mereka yang tidak melaksanakan pendaftaran penduduk. Oleh karena itu perlu peraturan yang juga mengatur sanksi berupa penghargaan dan hukuman (reward and punishment). Mereka yang 
berperilaku sesuai dengan norma yang berlaku (tertib administrasi kependudukan) mendapatkan penghargaan dari pemerintah atau masyarakat. Sebaliknya yang melanggar, mendapat hukuman. Bentuk dan berat ringannya hukuman tergantung kepada berat ringannya pelanggaran terhadap norma yang berlaku dan sejauhmana norma tersebut telah melembaga dan membudaya dalam masyarakat.

\section{PELEMBAGAAN KEPENDUDUKAN}

NORMA

TERTIB

ADMINISTRASI

Untuk menumbuhkan norma tertib administrasi kependudukan diperlukan suatu proses sosialisasi untuk mengenalkan, membiasakan dan selanjutnya membudayakan. Agar norma tertib administrasi kependudukan dapat diterima oleh masyarakat diperlukan deskripsi yang jelas serta dapat diikuti oleh masyarakat. Masyarakat juga perlu diyakinkan mengenai manfaat yang dapat diperoleh dengan melakukan tertib administrasi kependudukan. Dalam hal ini perilaku tertib administrasi kependudukan dapat dideskripsikan sebagai kesediaan masyarakat untuk mendaftarkan dan mencatatkan secara sukarela semua keadaan dan status penduduk yang dikarenakan oleh kejadian vital sesuai dengan perundang-undangan yang berlaku.

\section{Sumber Acuan}

Agusta, I. 2000. Asumsi-asumsi Program Pemberdayaan Masyarakat Pedesaan di Indonesia. Mimbar Sosek: Jurnal Sosial Ekonomi Pertanian Vol. 13 No. 1/2000. Jurusan Ilmu-ilmu Sosial Ekonomi Pertanian, Fakultas Pertanian IPB. Bogor.

Bienen, H., D. Kapur, J. Park dan J. Riedinger. 1990. Decentralization in Nepal. World Development, 18: 61-75.

Dharmawan, A.H. 2006. Konflik-konflik Kekuasaan dan Otoritas Kelembagaan Lokal dalam Reformasi Tata-Kelola Pemerintahan Desa: Infestigasi Teoritik dan Empirik. Pembaharuan Tata-Kelola Pemerintahan Desa Berbasiskan Kemitraan. Working Paper Series No. 01. Kerjasama Pusat Studi Pembangunan Pertanian dan Pedesaan, LPPM-IPB dengan Kemitraan bagi Pembangunan Tata Pemerintahan di Indonesia. Bogor.

Haryanto, R. dan B. Sugeng. 2001. Pembangunan Administrasi Kependudukan dalam Otonomi Daerah. Jurnal Sosiologi Indonesia No. 5/2001. Ikatan Sosiologi Indonesia. Jakarta. 
Haryanto, R. dan S.M.P. Tjondronegoro. 2001. Penanggulangan Kemiskinan dalam Otonomi Daerah: Pembaharuan Wacana dalam Penetapan Sasaran dan Pemilihan Instrumen yang Lebih Sesuai Kebutuhan Daerah. Jurnal Sosiologi Indonesia No. 5/2001. Ikatan Sosiologi Indonesia. Jakarta.

Ingham, B. dan A.K.M. Kalam. 1992. Decentralization and Development: Theory and Evidence from Bangladesh. Publik Administration and Development, 12: 373-385.

Maro, P.S. 1994. The Impact of Decentralization on Spatial Equity and Rural Development in Tanzania. World Development, 18: 673-693.

Mustari, A. 1999. Otonomi Daerah dan Kepala Daerah Memasuki Abad XXI. Gaya Media Pratama. Cetakan Kedua. Jakarta.

Tetiani, A. 2002. Masalah Struktural Utang Luar Negeri untuk Proyek Pembangunan Desa. Mimbar Sosek: Jurnal Sosial Ekonomi Pertanian Vol. 15 No. 1/2002. Jurusan Ilmu-ilmu Sosial Ekonomi Pertanian, Fakultas Pertanian IPB. Bogor.

Utomo, B.S. 1998. Program Jaring Pengaman Sosial (JPS) dan Masalahmasalahnya. Mimbar Sosek: Jurnal Sosial Ekonomi Pertanian Vol. 11

No. 2 Agustus 1998. Jurusan Ilmu-ilmu Sosial Ekonomi Pertanian Fakultas Pertanian IPB. Bogor.

Wahyuni, E. S. 2003. Mobilitas Penduduk di Indonesia dan Otonomi Daerah. Mimbar Sosek: Jurnal Sosial Ekonomi Pertanian Vol. 16 No. 2/2003. Jurusan Ilmu-ilmu Sosial Ekonomi Pertanian, Fakultas Pertanian IPB. Bogor.

Zuhro, S. 1999. Perjuangan Panjang Menegakkan Otonomisasi. Jurnal Otonomi, Vol. 1, No. 1. 